Article

\title{
The Polyextreme Ecosystem, Salar de Huasco at the Chilean Altiplano of the Atacama Desert Houses Diverse Streptomyces spp. with Promising Pharmaceutical Potentials
}

\author{
Carlos Cortés-Albayay ${ }^{1,2,3,4}$, Johanna Silber ${ }^{5}$, Johannes F. Imhoff ${ }^{5}$ (D) Juan A. Asenjo ${ }^{3}$, \\ Barbara Andrews ${ }^{3}$, Imen Nouioui ${ }^{4, *}$ and Cristina Dorador $1,2, *$ (D) \\ 1 Laboratory of Microbial Complexity and Functional Ecology, Centre for Biotechnology and \\ Bioengineering-CeBiB, University of Antofagasta, Av. Angamos, Antofagasta 601, Chile; \\ c.j.cortesbt@gmail.com \\ 2 Department of Biotechnology, Faculty of Marine Science and Biological Resources, \\ University of Antofagasta, Av. Angamos, Antofagasta 601, Chile \\ 3 Centre for Biotechnology and Bioengineering-CeBiB, Department of Chemical Engineering and \\ Biotechnology, University of Chile, Beauchef, Santiago 851, Chile; juasenjo@ing.uchile.cl (J.A.A.); \\ bandrews@ing.uchile.cl (B.A.) \\ 4 School of Natural and Environmental Sciences, Newcastle University, Newcastle upon Tyne NE1 7RU, UK \\ 5 GEOMAR Helmholtz-Zentrum für Ozeanforschung Kiel, Düsternbrooker Weg 20, D-24105 Kiel, Germany; \\ jsilber@geomar.de (J.S.); jimhoff@geomar.de (J.F.I.) \\ * Correspondence: imen.nouioui@newcastle.ac.uk (I.N.); cristina.dorador@uantof.cl (C.D.)
}

Received: 18 February 2019; Accepted: 24 April 2019; Published: 28 April 2019

\begin{abstract}
Salar de Huasco at the Chilean Altiplano of the Atacama Desert is considered a polyextreme environment, where solar radiation, salinity and aridity are extremely high and occur simultaneously. In this study, a total of 76 bacterial isolates were discovered from soil samples collected at two different sites in the east shoreline of Salar de Huasco, including H0 (base camp next to freshwater stream in the north part) and H6 (saline soils in the south part). All isolated bacteria were preliminarily identified using some of their phenotypic and genotypic data into the genera Streptomyces (86\%), Nocardiopsis $(9 \%)$, Micromonospora (3\%), Bacillus (1\%), and Pseudomonas (1\%). Streptomyces was found dominantly in both sites ( $\mathrm{H0}=19$ isolates and $\mathrm{H} 6=46$ isolates), while the other genera were found only in site H0 (11 isolates). Based on the genotypic and phylogenetic analyses using the 16S rRNA gene sequences of all Streptomyces isolates, $18 \%$ (12 isolates) revealed $<98.7 \%$ identity of the gene sequences compared to those in the publicly available databases and were determined as highly possibly novel species. Further studies suggested that many Streptomyces isolates possess the nonribosomal peptide synthetases-coding gene, and some of which could inhibit growth of at least two test microbes (i.e., Gram-positive and Gram-negative bacteria and fungi) and showed also the cytotoxicity against hepatocellular carcinoma and or mouse fibroblast cell lines. The antimicrobial activity and cytotoxicity of these Streptomyces isolates were highly dependent upon the nutrients used for their cultivation. Moreover, the HPLC-UV-MS profiles of metabolites produced by the selected Streptomyces isolates unveiled apparent differences when compared to the public database of existing natural products. With our findings, the polyextreme environments like Salar de Huasco are promising sources for exploring novel and valuable bacteria with pharmaceutical potentials.
\end{abstract}

Keywords: bioactive compounds; actinobacteria; Atacama; bioprospecting; Chilean Altiplano 


\section{Introduction}

Actinomycetes are the most important bacteria that are capable of producing bioactive compounds. The majority of natural products for new pharmaceutical applications are derived from actinomycetes [1], while the notable member of actinomycetes, the genus Streptomyces is the major producer [2]. Many of these specialized metabolites biosynthesized by actinomycetes correspond to polyketides and nonribosomal peptides, which may act as antibiotics, immunosuppressants, anticancer/antitumor agents, toxins, and siderophores [3]. The members of the genus Streptomyces are widely distributed across various habitats and geographical locations [4]. Streptomyces produces spores that are characteristically resistant, allowing this bacterium to persist in the extreme environments and to maintain its viability for many years [5]. Previous studies showed that bacteria isolated from the extreme environments, such as the Mariana Trench [6], the polar and permafrost soils in the Arctic [7,8], and the extremely dry and saline soils of the Atacama Desert [9] are unique sources for the discovery of new bioactive compounds and many of them are possibly novel species [5,10,11].

The Atacama Desert is the driest place in the world located in South America, precisely in Chile, covering a 1000-km strip of land on the Pacific coast, west of the Andes Mountains. It is bordering Peru in the north and extending to the Copiapó River in the south. Nowadays, four novel Streptomyces species derive from this extreme desert, including Streptomyces atacamensis [12], Streptomyces desertii [13], Streptomyces bulli [14], and Streptomyces leeuwenhoekii [15]. S. leeuwenhoekii is the producer of two newly bioactive compounds comprised of (i) chaxamycins, showing antagonism against Staphylococcus aureus ATCC 25923, inhibiting the heat shock protein 90, and degrading proteins involved in cell proliferation [9] and (ii) chaxalactins, the anti-Gram-positive bacterial agents [16]. Two more novel compounds, atacamycins and chaxapeptin, each derive respectively from Streptomyces sp., C38 [17] and C58 [18] isolated from hyper-arid soil of the Laguna de Chaxa of Salar de Atacama in the north of Chile (a lagoon located in the commune of San Pedro de Atacama, province of El Loa). These two compounds are novel lasso-peptides produced by nonribosomal biosynthesis with post-translational modification and capable of inhibiting human lung cancer cell line A549. Another group of new compounds with antimicrobial activity, the abenquines A-D, was obtained from Streptomyces sp. DB634 isolated from the Salar de Tara in the Chilean Altiplano (>4000 m.a.s.l.) [19].

In Chile, the Chilean Altiplano of the Atacama Desert, is considered the highest plateau of the Andes Mountains (>3000 m.a.s.l.) with $14^{\circ}$ to $22^{\circ} \mathrm{S}$ of latitude, in addition, it is subjected to strong climatic variation over different temporal scales [19]. This site offers a unique ecosystem with highly extreme conditions, such as changes in daily temperature from -10 to $+25{ }^{\circ} \mathrm{C}$ [19] and it divides into different sites, for instance, Salar de Tara (at $150 \mathrm{~km}$ east of the town of San Pedro de Atacama, in the Province of El Loa, region Antofagasta) and Salar de Huasco (in the south of the town of Parinacota in the Arica and Parinacota regions). The Salar de Huasco is known by its polyextreme conditions, i.e., salinity gradient (from freshwater to saturation), elevated levels of solar radiation $\left(<1100 \mathrm{~W} / \mathrm{m}^{2}\right)$, and negative water balance, which differs from the other locations previously studied in the Atacama Desert. Some areas of the Salar de Huasco have been found to house diverse microbes [20,21]. However, there is no study regarding the cultivable actinomycetes from this polyextreme ecosystem and their pharmaceutical potentials. Here, we aim to isolate bacteria with a focus on actinomycetes from different sites of the Salar de Huasco and to assess their pharmaceutical potentials in possession of nonribosomal peptide synthases (NRPS)-coding gene, antimicrobial activity, and cytotoxicity.

\section{Materials and Methods}

\subsection{Isolation of Actinomyces}

Six soil samples were collected from sites H0 (base camp; freshwater stream) and H6 (saline soils) located in the northern and southern parts of the eastern shoreline of the Salar de Huasco, respectively [22] (Figure 1). Sites $\mathrm{H} 0$ and $\mathrm{H} 6$ were characterized as meso-saline and hyper saline sites with $\mathrm{pH} 7.6$ and $\mathrm{pH} 8.6$, respectively [23]. The samples were taken at $5 \mathrm{~cm}$ depth from the ground 
surface using sterile polypropylene tubes and transferred to the laboratory. These samples were stored at ambient temperature for a period not exceeding 5 days. One $g$ of soil sample was suspended in $9 \mathrm{~mL}$ of $\frac{1}{4}$ strength Ringer's solution, and $1 \mathrm{~mL}$ of the soil suspension was diluted 100-fold and mixed in an orbital shaker at $150 \mathrm{rpm}$ for $1 \mathrm{~h}$. The diluted soil suspension was pretreated by heating at $55^{\circ} \mathrm{C}$ for $6 \mathrm{~min}$ in a thermo-regulated bath [4]. The heated aliquot $(0.1 \mathrm{~mL})$ was spread over the surface of starch casein agar medium (SCA), supplemented with $50 \mu \mathrm{g} / \mathrm{mL}$ nystatin and $50 \mu \mathrm{g} / \mathrm{mL}$ cycloheximide to prevent fungal contamination [24]. All seeded agar plates were prepared in triplicate and incubated at $28^{\circ} \mathrm{C}$ for 14-21 days [25]. Colonies with rough appearance, powdery or tough texture and branching filaments with and without aerial mycelia were subcultured on SCA plates and incubated at $28^{\circ} \mathrm{C}$ for 14 days. A subculture of each isolate was prepared on International Streptomyces Project III (ISP3) medium [26] under the same condition cited above. The purity of the each isolates was checked using light microscope.

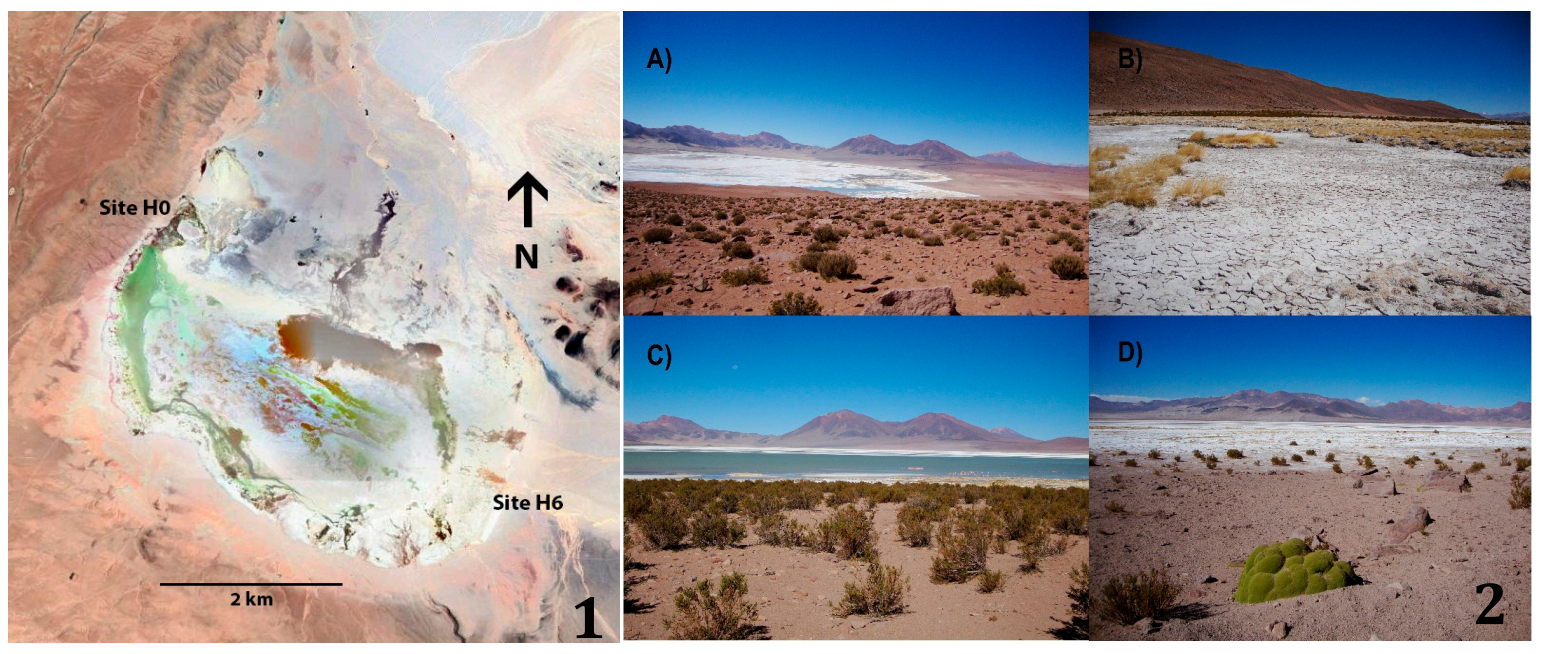

Figure 1. 1: Satellite image of Salar de Huasco indicating sampling sites. Image Google Earth $\mathrm{V}$ 7.3.2.5776. (3 March 2019). Salar de Huasco, Chile. $20^{\circ} 16^{\prime} 22.68^{\prime \prime}$ S, $68^{\circ} 52^{\prime} 54.08^{\prime}$ W, Eye alt 14.35 mi. CNES/Airbus 2019 [30 March 2019]. https://earth.google.com/web/@-20.29749527,-68.84083051, 3780.51679815a,17347.67437889d,35y,360h,0t,0r. 2: Sampling sites at Salar de Huasco, Northern Chile.

(A) Panoramic view of Salar de Huasco, Chilean Altiplano; (B) Site H0, saline crusts; (C) Site H6, soils;

(D) Site H6, saline soils.

\subsection{Identification of Bacterial Isolates}

\subsubsection{Morphological Characterization Based on Color Grouping}

The morphological characteristics of all bacterial isolates grown on ISP3 medium, such as aerial spore mass color, pigmentation of vegetative or substrate mycelium, and the production of diffusible pigment were examined. The color of the aerial and substrate mycelium of the isolates were described referring to the National Bureau of Standards (NBS) Color Name Charts [27]. Each isolate was maintained on glucose yeast extract and malt extract (GYM) medium and stored as spore suspensions and hyphae in $25 \%(v / v)$ glycerol at $-80^{\circ} \mathrm{C}$.

\subsection{2. $16 \mathrm{~S}$ rRNA Gene-Based Phylogenetic Analysis}

Bacterial cultures were prepared in tryptone yeast extract (ISP1) broth at $28^{\circ} \mathrm{C}$ for 7 days, in which $2 \mathrm{~mL}$ was transferred to vials containing $0.5 \mathrm{~mm}$ glass beads (BioSpec Products Inc, Bartlesville, OK, USA) to breakdown mechanically the bacterial cells (Mini Bead Beater, Bead Homogenizer, BioSpec Products Inc, Bartlesville, OK, USA). Total genomic DNA was extracted from the homogenized bacterial suspension using the AxyPrep Bacterial Genomic DNA Miniprep kit (Axygen Biosciences, Union City, NJ, USA) as recommended by the manufacturer. 
The 16S rRNA gene was amplified by PCR using the universal primers for bacteria, Eub9-27F and Eub1542R [28]. Every reaction was performed in a final volume of $50 \mu \mathrm{L}$, containing $50-100 \mathrm{ng}$ of genomic DNA, $2.0 \mu \mathrm{M}$ of each primer, $19 \mu \mathrm{L}$ of nuclease-free MilliQ- $\mathrm{H}_{2} \mathrm{O}$ (Merck Millipore, Burlington, MA, USA), and $25 \mu \mathrm{L}$ of SapphireAmp ${ }^{\circledR}$ Fast PCR Master Mix (TaKaRa, Japan). PCR was carried out in a thermocycler under the following conditions: Initial denaturation at $94{ }^{\circ} \mathrm{C}$ for $5 \mathrm{~min}, 30$ cycles of denaturation at $94{ }^{\circ} \mathrm{C}$ for $45 \mathrm{~s}$, annealing at $54{ }^{\circ} \mathrm{C}$ for $45 \mathrm{~s}$, and extension at $72{ }^{\circ} \mathrm{C}$ for $1.5 \mathrm{~min}$, and a final extension at $72{ }^{\circ} \mathrm{C}$ for $5 \mathrm{~min}$. The PCR (Polymerase Chain Reaction) products were checked by $1 \%$ $(w / v)$ agarose gel electrophoresis and subsequently sequenced by capillary sequencing using an ABI Prism 3730XL automated DNA sequencer (Applied Biosystems, Macrogen Inc., Seoul, Korea).

The 16S rRNA gene sequences were analyzed and edited using the software DNA Baser Sequence Assembler version 3.5 (Heracle BioSoft SRL, 2014). The partial 16S rRNA gene sequences of the isolates were aligned using RDP II [29]. EzTaxon [30] was used to retrieve the nearest phylogenetic neighbors of all bacterial isolates. The nearly completed $16 \mathrm{~S}$ rRNA gene sequences $(>1300 \mathrm{nt})$ of the isolates were deposited in the GenBank database with the accession numbers KX130868-KX130886.

The phylogenetic tree was constructed using Neighbor-Joining algorithms [31] with a Tamura-Nei substitution model using MEGA 7.0 software [32]. The multiple alignments of all the 16S rRNA gene sequences were performed using MUSCLE (MUltiple Sequence Comparison by Log- Expectation) algorithm [33]. The robustness of the tree was evaluated using 1000 Bootstrap [34].

\subsection{Evaluations of Pharmaceutical Potentials}

\subsubsection{Genotyping of Nonribosomal Peptide Synthetase (NRPS)}

Streptomyces isolates with nearly complete 16S rRNA gene sequences were screened for the presence of nonribosomal peptide synthetase (NRPS) domains using the primers A3F (5'-GCSTACSYSATS TACACSTCSGG-3') and A7R (5'-SASGTCVCCSGTSCGGTAS-3') following a method described by Ayuso-Sacido and Genilloud [35].

\subsubsection{Preparation of Crude Extracts and Bioactivity Assessments}

The secondary metabolites were extracted from Streptomyces isolates possessing NRPS domains following a protocol described by Schneemann et al. [36] with some modifications. Each isolate was grown in $100 \mathrm{~mL}$ of GYM (pH 7.2), and in starch-soy peptone (SPM, pH 7.0) liquid media supplemented with $2 \% \mathrm{NaCl}$ and incubated at $28{ }^{\circ} \mathrm{C}$ for one week, with shaking at $135 \mathrm{rpm}$, in an orbital shaking incubator (MaxQ 4000, Thermo Fisher Scientific, Waltham, MA, USA). Extraction of metabolites from the whole culture broths started with the addition of $150 \mathrm{~mL}$ of ethyl acetate to each flask, followed by stirring and sonication cycles and kept at $4{ }^{\circ} \mathrm{C}$ overnight for effective phase separation. The lower aqueous phase was discarded, and the ethyl acetate phase (supernatant) was dried in a rotary evaporator (Büchi, Flawil, Switzerland) at ambient temperature.

The antimicrobial activity of the crude extracts was evaluated by bioassays using stocks solutions with a concentration of $1 \% w / v$ (equivalent to $10 \mathrm{mg} / \mathrm{mL}$ in methanol). The bioassays of antibacterial and antifungal activities were performed following a procedure described by Schneemann et al. [36]. Aliquot of $5 \mu \mathrm{L}$ of each crude extract was added in each well of the 96-well microtiter plate and then the solvent was evaporated using vacuum centrifuge (Biotage SPE Dry, Uppsala, Sweden) before append $195 \mu \mathrm{L}$ of the test microbial suspension. The final concentration of each crude extract in the bioassays was $250 \mu \mathrm{g} / \mathrm{mL}$. The test organisms comprised of gram-positive bacteria: Staphylococcus epidermidis DSM 20044 ${ }^{\mathrm{T}}$, methicillin-resistant Staphylococcus aureus DSM 18827, Pseudomonas aeruginosa DSM 50071 ${ }^{\mathrm{T}}$, and Propionibacterium acnes DSM $1897^{\mathrm{T}}$, gram-negative bacteria: Xanthomonas campestris DSM 2405 and Erwinia amylovora DSM 50901, and fungi: Candida albicans DSM 1386, Trichophyton rubrum, Septoria tritici, and Phytophthora infestans. Trichophyton rubrum was obtained from F. Horter (Department of Dermatology, Allergology, and Venerology, University Hospital Schleswig-Holstein, Kiel, Germany while Septoria tritici and Phytophthora infestans were obtained from Dr. J. B. Speakman 
(BASF, Ludwigshafen, Germany). The positive control for the test bacteria was $100 \mu \mathrm{g} /$ well of chloramphenicol and that for the test fungi was $200 \mu \mathrm{g} /$ well of cycloheximide, while the negative control was no compound applied.

The cytotoxicity test was performed following a method described by Schulz et al. [19]. Aliquot $(1 \mu \mathrm{L})$ of each crude extract was added in a final assay volume of $100 \mu \mathrm{L}$ of the mouse fibroblasts (NIH-3T3) and hepatocellular carcinoma (HepG2 ACC 180) cell lines. NIH-3T3 cell line was provided by G. Rimbach, University of Kiel, Germany while HepG2 ACC 180 was obtained from Leibniz Institute DSMZ-German collection of microorganisms and cell cultures, Braunschweig, Germany. The final concentration of each crude extract in the bioassays was $100 \mu \mathrm{g} / \mathrm{mL}$. The positive control for these assays was tamoxifen with a final concentration of $40 \mu \mathrm{M}$. No compound was added for the negative control.

\subsubsection{Profiling of Metabolites in Crude Extracts}

The crude extracts dissolved in methanol were elucidated by analytical reversed-phase HPLC-UV-MS (High-Performance Liquid Chromatography with UV detector coupled to Mass Spectrometry), in a VWR-Hitachi La-Chrom Elite System, coupled to a diode array detector and a Phenomenex Onyx Monolithic column $(\mathrm{C} 18,100 \times 3.00 \mathrm{~mm})$ according to the conditions described by Silber et al. [37]. For the mass detection, the HPLC system was coupled to an ion trap detector (Esquire4000, Bruker Daltonics, Billerica, MA, USA). The UV-Vis spectra of peaks obtained from each bacterial crude extract were compared with the Dictionary of Natural Products 2012 [38].

\section{Results and Discussion}

\subsection{Selective Isolation and Identification of the Isolates}

A number of 30 and 46 isolates were obtained from soils samples of sites $\mathrm{H} 0$ and $\mathrm{H} 6$, respectively. These isolates were obtained from plates with 10 fold dilutions, and $97 \%$ (74 isolates) of them were found to be affiliated with the phylum Actinobacteria based on the 16S rRNA gene sequence similarity. Two isolates were classified as Bacillus and Pseudomonas, while the others belong to Nocardiopsis (7 isolates), Micromonospora (2 isolates), and Streptomyces (65 isolates) (Table 1).

Table 1. 16S rRNA gene-based identification of all bacteria isolated from Salar de Huasco.

\begin{tabular}{|c|c|c|c|c|}
\hline Class & Family & Genus & Number of Isolate (\%) & Site of Isolation \\
\hline \multirow{3}{*}{ Actinobacteria } & Streptomycetaceae & Streptomyces & $65(86 \%)$ & $\mathrm{H} 0$ and $\mathrm{H} 6$ \\
\hline & Nocardiopsaceae & Nocardiopsis & $7(9 \%)$ & H0 \\
\hline & Micromonosporaceae & Micromonospora & $2(3 \%)$ & $\mathrm{H} 0$ \\
\hline Bacilli & Bacillaceae & Bacillus & $1(1 \%)$ & $\mathrm{HO}$ \\
\hline Gammaproteobacteria & Pseudomonadaceae & Pseudomonas & $1(1 \%)$ & $\mathrm{HO}$ \\
\hline
\end{tabular}

The eleven non-Streptomyces isolates were found only in the soil sample with neutral $\mathrm{pH} 7.6$ collected from site H0, while the majority of the Streptomyces isolates (40) were obtained from the hypersaline site $\mathrm{H} 6$ with $\mathrm{pH}$ 8.6. All 65 Streptomyces isolates were subdivided into three color grouping after incubation on ISP3 agar medium at $28{ }^{\circ} \mathrm{C}$ for 14 days (Table 2). They showed the typical morphology of the genus Streptomyces in formation of aerial mycelium and spore chains. Most of these isolates produced diffusible pigments and excreted colored aqueous droplets on the hydrophobic surface of their colonies. 
Table 2. Morphological and molecular characteristics of some Streptomyces spp. ${ }^{a}$ isolated from Salar de Huasco.

\begin{tabular}{|c|c|c|c|c|c|c|c|c|}
\hline \multirow[b]{2}{*}{$\begin{array}{l}\text { Isolate } \\
\text { Code }\end{array}$} & \multirow[b]{2}{*}{$\begin{array}{l}\text { Site of } \\
\text { Isolation }\end{array}$} & \multicolumn{3}{|c|}{ Morphological Characteristics ${ }^{b}$} & \multicolumn{4}{|c|}{ Molecular Characteristics } \\
\hline & & Aerial Spore Mass & $\begin{array}{l}\text { Substrate } \\
\text { Mycelium }\end{array}$ & $\begin{array}{l}\text { Diffusible } \\
\text { Pigments }\end{array}$ & Closest Type Strain & $\begin{array}{c}16 \text { rRNA Gene } \\
\text { Accession Number }\end{array}$ & $\begin{array}{l}\text { Similarity } \\
(\%)\end{array}$ & $\begin{array}{c}\text { NRPS } \\
\text { (Adenylation } \\
\text { Domain) }\end{array}$ \\
\hline HST05 & H6 & White & $\begin{array}{l}\text { Light yellowish } \\
\text { pink }\end{array}$ & - & Streptomyces canus DSM 40017 & KQ948708 & 96.8 & + \\
\hline HST09 & H6 & Dark greyish blue & Deep purplish red & - & Streptomyces lienomycini LMG $20091^{\mathrm{T}}$ & AJ781353 & 99.6 & + \\
\hline HST14 & H6 & White & Pale violet & $\begin{array}{l}\text { Light greyish } \\
\text { brown }\end{array}$ & Streptomyces atroolivaceus NRRL ISP-5137 & JNXG01000049 & 96.0 & - \\
\hline HST18 & H6 & - & Dark olive green & $\begin{array}{l}\text { Moderate } \\
\text { yellow green }\end{array}$ & Streptomyces alboniger NRRL B- $1832^{\mathrm{T}}$ & LIQN01000245 & 96.7 & + \\
\hline HST19 & H6 & Dark greyish blue & $\begin{array}{l}\text { Dark greenish } \\
\text { yellowish green }\end{array}$ & $\begin{array}{l}\text { Dark greyish } \\
\text { yellowish } \\
\text { brown }\end{array}$ & Streptomyces collinus NBRC $12759^{\mathrm{T}}$ & AB184123 & 99.2 & + \\
\hline HST21 & H6 & White & Greyish yellow & $\begin{array}{l}\text { Moderate olive } \\
\text { brown }\end{array}$ & Streptomyces albidochromogenes NBRC $101003^{\mathrm{T}}$ & AB249953 & 99.1 & + \\
\hline HST22 & H6 & White & Deep orange yellow & $\begin{array}{l}\text { Moderate olive } \\
\text { brown }\end{array}$ & Streptomyces albidochromogenes NBRC $101003^{\mathrm{T}}$ & AB249953 & 99.0 & + \\
\hline HST23 & $\mathrm{H} 6$ & Light pink & Light orange yellow & Dark yellow & Streptomyces purpureus NBRC $13927^{\mathrm{T}}$ & AB184547 & 98.8 & - \\
\hline HST28 & H6 & White & Light olive brown & Dark brown & Streptomyces kanamyceticus NBRC $13414^{\mathrm{T}}$ & AB184388 & 98.8 & + \\
\hline HST50 & H6 & White & $\begin{array}{l}\text { Greyish reddish } \\
\text { brown }\end{array}$ & - & Streptomyces ambofaciens ATCC $23877^{\mathrm{T}}$ & СР012382 & 96.0 & - \\
\hline HST51 & H6 & Light pink & $\begin{array}{l}\text { Strong yellowish } \\
\text { brown }\end{array}$ & - & Streptomyces alboniger NRRL B- $1832^{\mathrm{T}}$ & LIQN01000245 & 98.6 & + \\
\hline HST54 & H6 & White & Deep red & $\begin{array}{l}\text { Light greyish } \\
\text { brown }\end{array}$ & Streptomyces griseolus NRRL B-2925 & JOFC01000069 & 97.6 & - \\
\hline HST61 & H6 & Pale yellowish pink & Pale orange yellow & - & Streptomyces kanasensis $\mathrm{ZX01}{ }^{\mathrm{T}}$ & JN572690 & 99.6 & - \\
\hline HST66 & H6 & White & $\begin{array}{l}\text { Deep greenish } \\
\text { yellow }\end{array}$ & - & Streptomyces fumanus NBRC $13042^{\mathrm{T}}$ & AB184273 & 96.9 & + \\
\hline HST68 & H6 & Greyish blue & Pinkish grey & - & Streptomyces ambofaciens ATCC $23877^{\mathrm{T}}$ & СР012382 & 96.0 & + \\
\hline HST69 & Ho & White & Brilliant yellow & - & Streptomyces chlorus $\mathrm{BK} 125^{\mathrm{T}}$ & LIQN01000245 & 98.1 & + \\
\hline HST72 & Ho & White & $\begin{array}{l}\text { Strong yellowish } \\
\text { brown }\end{array}$ & Strong brown & Streptomyces microflavus NBRC $13062^{\mathrm{T}}$ & AB184284 & 97.9 & - \\
\hline HST82 & Ho & White & Pale yellowish pink & - & Streptomyces cyaneofuscatus NRRL B- $2570^{\mathrm{T}}$ & JOEM01000050 & 95.6 & - \\
\hline HST83 & Ho & White & $\begin{array}{l}\text { Strong yellowish } \\
\text { brown }\end{array}$ & Strong brown & Streptomyces pratensis ch $24^{\mathrm{T}}$ & JQ806215 & 97.8 & + \\
\hline
\end{tabular}

${ }^{a}$ These Streptomyces isolates were selected based on the quality of their $16 \mathrm{~S}$ rRNA gene sequences (>1300 nt). ${ }^{b}$ The morphological characteristics were observed after growing Streptomyces isolates on ISP3 agar medium at $28^{\circ} \mathrm{C}$ for 14 days. 
Nineteen out of 65 Streptomyces isolates were selected for further study based on their nearly complete $16 \mathrm{~S}$ rRNA gene sequences $(>1300 \mathrm{bp})$. These 19 isolates widely distributed across the phylogenetic tree of the genus Streptomyces supported by high bootstrap values as shown in Figure 2 . A total of 12 isolates showed a 16S rRNA gene sequence similarity below the $98.7 \%$ threshold for proposing as novel species [39] (Table 2), while the other seven (HST09, HST19, HST21, HST22, HST23, HST28, and HST61) found to occupy distinct phylogenetic positions from their closest relatives with no close relationship with any species and type strains of the genus Streptomyces from the Atacama Desert described so far [11-15] (Figure 2).

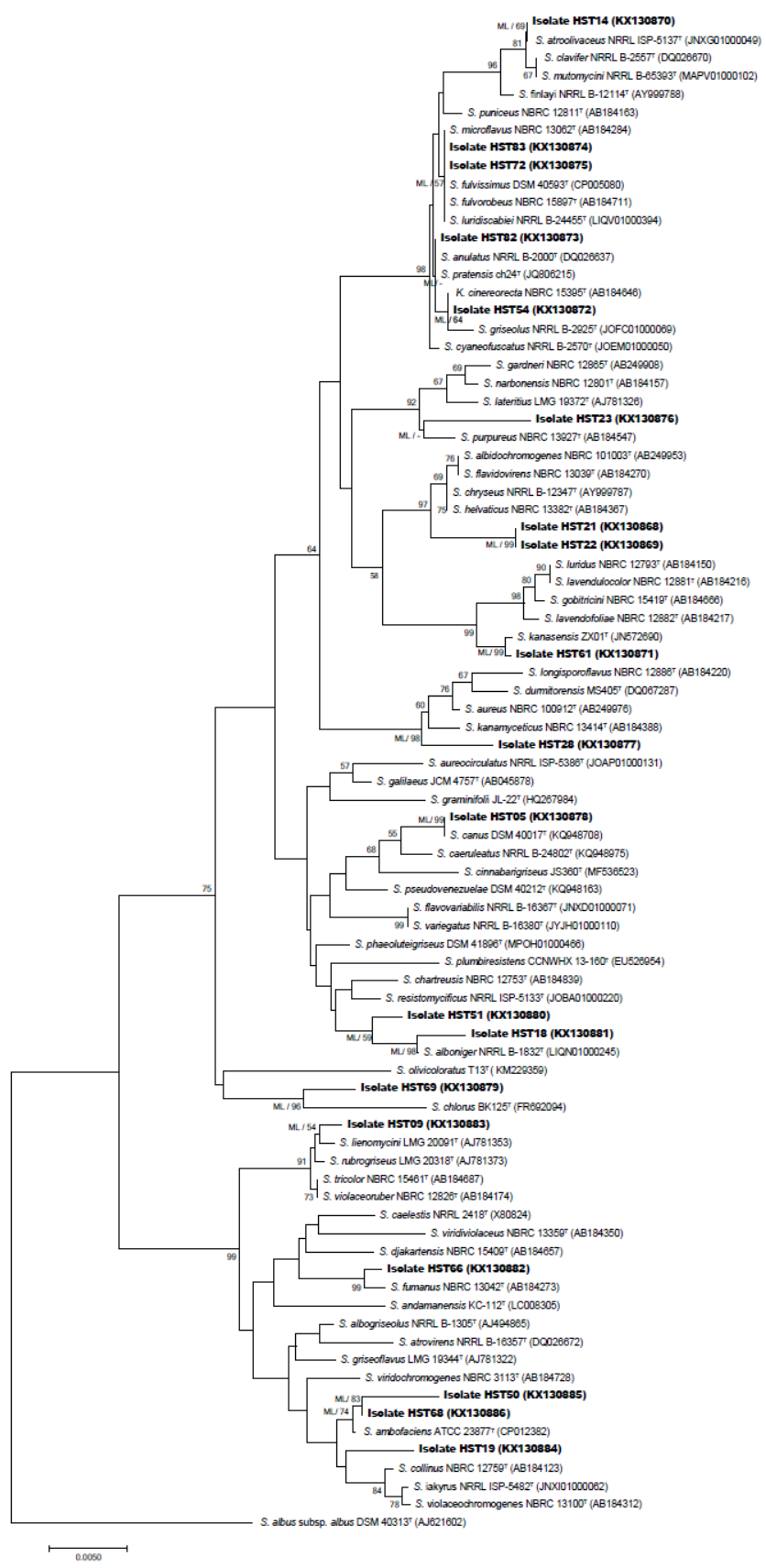

Figure 2. Neighbor-joining phylogenetic tree based on almost complete 16S RNA sequences (>1300 nt) of the 19 Streptomyces isolates derived from Salar de Huasco and their closely related species. The tree was constructed using the Neighbor-Joining algorithm and the Jukes-Cantor substitution model. The scale bar indicates 0.005 substitutions per nucleotide, and Streptomyces albus subsp. albus DSM $40313^{\mathrm{T}}$ was used as an out-group. Bootstrap values above $50 \%$ are present. 
Isolate HST19 forms a distinct branch closely related to the type strain of Streptomyces collinus NBRC $12759^{\mathrm{T}}(99.2 \%)$ [40], Streptomyces iakyrus NRRL ISP-5482 ${ }^{\mathrm{T}}(98.8 \%)$ [41], and Streptomyces violaceochromogenes NBRC $13100^{\mathrm{T}}$ (99.3\%) [42]. Isolates HST21 and HST22 form a well-supported sub-clade closely associated to Streptomyces albidochromogenes NBRC $101003^{\mathrm{T}}(99.0 \%)$ [43]. Strain HST61 occupied a phylogenetic position close to "Streptomyces kanasensis" ZX01 (99.6\%) which is a producer of a novel antiviral glycoprotein [44]. Isolate HST28 showed close phylogenetic relationship with Streptomyces kanamyceticus NBRC $13414^{\mathrm{T}}(98.8 \%)$ [45], while isolate HST23 had close relatedness to Streptomyces purpureus NBRC $13927^{\mathrm{T}}(98.8 \%)$ [46]. Isolates HST09 occupied distant subclade closely related to Streptomyces lienomycini LMG 20091 ${ }^{\mathrm{T}}$ (99.6\%) [43].

The length of the branch of all Streptomyces isolates in the phylogenetic tree and the assignation to these isolates to completely different clades from each other, except for isolates HST21 and HST22, highlight the divergence of them from their closely related neighbors. Further studies need to be performed to confirm the right affiliations of these isolates to the novel species within the evolutionary radiation of the genus Streptomyces.

Most isolates (except for isolates HST83, HST72, HST21, and HST22) showed divergent phylogenetic positions compared to the type species of the genus Streptomyces (Figure 2). Therefore, these strains should be designed for further taxonomic and analytical chemistry analyses to confirm their novelty at species rank and as a source of novel chemical entities (Table 3).

Table 3. Bioactivities of crude extracts derived from Streptomyces spp. of Salar de Huasco.

\begin{tabular}{|c|c|c|c|c|c|c|c|c|c|c|c|}
\hline \multirow{4}{*}{$\begin{array}{l}\text { Crude Extract } \\
\text { Derived From } \\
\text { Streptomyces } \\
\text { Isolate Grown in } \\
\text { Different Media }\end{array}$} & \multicolumn{11}{|c|}{ Growth Inhibition (\%) ${ }^{a}$} \\
\hline & \multicolumn{5}{|c|}{ Antibacterial Activity } & \multirow{2}{*}{\multicolumn{4}{|c|}{ Antifungal Activity }} & \multirow{2}{*}{\multicolumn{2}{|c|}{ Cytotoxicity }} \\
\hline & \multicolumn{3}{|c|}{ Gram-Positive Bacteria } & \multicolumn{2}{|c|}{ Gram-Negative Bacteria } & & & & & & \\
\hline & Se & MRSA & $\mathbf{P a}$ & $X_{c}$ & Ea & $\mathrm{Ca}$ & Tru & Sep & PhA & NIH-3T3 & HepG2 \\
\hline HST09-GYM & 96 & 92 & - & 27 & - & - & 72 & - & - & 99 & 79 \\
\hline HST09-SPM & 28 & 28 & - & - & - & - & - & - & - & 36 & - \\
\hline HST14-SPM & - & - & - & - & - & - & 30 & - & - & 51 & 42 \\
\hline HST19-GYM & - & - & 57 & 55 & - & - & 58 & - & - & 57 & 34 \\
\hline HST19-SPM & 61 & 60 & 53 & 76 & - & - & - & - & - & 20 & - \\
\hline HST21-GYM & 99 & 98 & - & 84 & 91 & - & 86 & 22 & 50 & 99 & 99 \\
\hline HST21-SPM & 97 & 95 & - & 79 & 96 & - & 100 & - & 53 & 99 & 99 \\
\hline HST23-GYM & 93 & 92 & 100 & 97 & 71 & 77 & 100 & 100 & 49 & 99 & 99 \\
\hline HST50-GYM & 96 & - & 90 & 97 & 92 & - & 41 & 29 & - & 43 & 38 \\
\hline HST50-SPM & 93 & 41 & 97 & 98 & - & - & 57 & 30 & - & - & - \\
\hline HST54-GYM & 96 & 95 & 96 & 78 & - & - & 48 & - & 39 & 53 & 24 \\
\hline HST54-SPM & 95 & 92 & 93 & 71 & - & - & 47 & - & 35 & 52 & 25 \\
\hline HST61-GYM & 73 & - & - & 76 & 63 & - & 59 & 59 & 22 & - & - \\
\hline HST61-SPM & 81 & 41 & - & 62 & 68 & - & 43 & 62 & 26 & - & - \\
\hline HST68-GYM & 93 & - & 90 & 97 & 91 & - & 30 & 21 & - & - & 21 \\
\hline HST68-SPM & 38 & - & 50 & 24 & - & - & 45 & - & - & - & - \\
\hline HST72-GYM & 95 & 97 & 98 & 35 & - & 28 & 60 & 100 & 47 & 97 & 69 \\
\hline HST72-SPM & 97 & 97 & 99 & 56 & - & - & 50 & 96 & 28 & 86 & 59 \\
\hline HST82-GYM & 100 & 97 & 90 & 92 & - & - & 41 & - & - & 50 & 40 \\
\hline
\end{tabular}

a The average results derived from triplicate assays are shown with inhibition percentage (\%) of growth of Se (Staphylococcus epidermis), MRSA (methicillin-resistant Staphylococcus aureus), Pa (Propionibacterium acnes), Xc (Xanthomonas campestris), Ea (Erwinia amylovora), Ca (Candida albicans), Tru (Trichophyton rubrum), Sep (Septoria tritici), Pha (Phytophthora infestans), NIH-3T3 (mouse fibroblasts), and HepG2 (hepatocellular carcinoma). GYM and SPM refer respectively to glucose yeast extract plus malt extract medium and starch-soy peptone medium, in which the Streptomyces isolates were grown before the preparation of their crude extracts. The negative results are shown with (-). 


\subsection{Secondary Metabolite Analysis}

The NRPSs are multimodular enzymatic complexes constituted by three main catalytic domains: The adenylation (A) domain, responsible for the recognition and activation of a specific amino acid, the condensation (C) domain catalyses the formation of the peptidic bond (C-N) between different modules, and the peptidyl-carrier $(\mathrm{T})$ domain which transfers the activated amino acids from the A domain to the $C$ domain of the same module [6]. The presence of A domain in actinobacterial genomes reflects the biosynthesis of secondary metabolites. The products of the NRPS biosynthetic pathway are diverse secondary metabolites including several antitumor compounds [47,48]. A total of 12 Streptomyces isolates (63\%) (Table 2) revealed the possession of NRPS A domain. A correlation has been previously observed between the numbers of isolates with the positive NRPS-PCR reaction and the production of bioactive compounds [36]. The 12 NRPS-holding isolates were tested further for their bioactivities. Isolates HST05, HST14, HST18 and HST51 were discarded from this analysis due to their low growth rate on the test media. From the pairs of isolates HST83-HST72 and HST21-HST22 that occupied the same phylogenetic position (Figure 2), we only included isolates HST21 and HST72 for the bioactivity tests.

The crude extracts obtained from Streptomyces isolates grown previously in GYM or SPM broth demonstrated the different HPLC profiles (Figure S1). These isolates have a wide range of metabolites in their chromatograms (Figure S1). The UV-Vis and MS data of the crude extracts in comparison with the Dictionary of Natural Products Database exhibited a low similarity to the known compounds, which highlights the novelty of these natural entities. The majority of the isolates showed high antifungal, antibacterial and cytotoxic activities (Table 3), supported by the high levels of growth inhibition $(>90 \%)$ against several pathogens, such as, MRSA (HST09, HST21, HST23, HST28, HST72, HST82, HST50, HST54, and HST68), P. acnes (HST23, HST23, HST28, HST50, HST54, and HST72), X. campestris (HST23, HST28, HST50, and HST68), and Trichophyton rubrumn (HST21 and HST23). The crude extracts at a final extract concentration of $100 \mu \mathrm{g} / \mathrm{mL}$ from isolates HST09, HST21, HST23, HST28, HST66, and HST72 also showed the high levels of cytotoxicity ( 99\%) against the tumor cell lines of HepG2 and NIH-3T3. Based on the overall bioactivities, isolates HST21, HST23, and HST28 were the producers of broad-spectrum antibiotics. These results are coherent with those described Streptomyces spp. isolated from the other Salar sites of the Atacama Desert, e.g., Streptomyces sp. C38 from Salar de Atacama that produces atacamycins A-C [17] and Streptomyces sp. DB634 from Salar de Tara that produces abenquines A-D [19].

The polyextreme ecosystem of Salar de Huasco forces the microorganisms to adapt to it [49], which led to the development of unique Streptomyces taxa that are clearly different from the other sites in the Atacama Desert and the Altiplano [9] and probably vary due to the spatial heterogeneity within the same area [50].

\section{Conclusions}

Streptomyces spp. isolated from the Salar de Huasco at the Chilean Altiplano showed taxonomic divergences from the species with validly published names and capabilities to produce novel secondary metabolites with interesting pharmaceutical potentials. These findings open up the prospect for novel drug discovery. Further analytical and chemical analyses should be carried out to elucidate these microbial products in order to be exploited for future biotechnological applications.

Supplementary Materials: The following are available online at http://www.mdpi.com/1424-2818/11/5/69/s1, Figure S1: HPLC-UV/Vis Chromatographic profiles of extracts obtained from culture metabolic extracts for analyzed strains, which were grown in liquid media GYM (A) and SPM (B) both of them at $\% \mathrm{NaCl}$.

Author Contributions: C.C.-A. carried out the experiments, analyzed the data and wrote the manuscript with support from I.N., C.D., J.A.A. and B.A. I.N. contributed to the interpretation of the results and helped in writing the manuscript. C.D. designed the experiments and supervised the work. J.S. and J.F.I. performed the bioassays tests and the mass spectrometry analyses. All the authors discussed the results and contributed to the final version of the manuscript. 
Funding: This study was supported by grants from DAAD-CONICYT Project 698, FONDECYT 1110953; 1140179 and by CONICYT with the PFCHA/DOCTORADO BECAS CHILE/2016-21160585 and the Basal Centre Grant for CeBiB (FB0001).

Acknowledgments: We acknowledge to Jaime Guerrero for his help in the field, Pablo Aguilar for sampling support, Diego Cornejo for technical support and the whole team of the Laboratory of Functional Ecology and Microbial Complexity of Antofagasta Institute, University of Antofagasta (Antofagasta, Chile).

Conflicts of Interest: The authors declare that the research was conducted in the absence of any commercial or financial relationships that could be construed as a potential conflict of interest.

\section{References}

1. Bérdy, J. Bioactive microbial metabolites. J. Antibiot. 2005, 58, 1-26. [CrossRef]

2. Watve, M.; Tickoo, R.; Jog, M.; Bhole, B. How many antibiotics are produced by the genus Streptomyces? Arch. Microbiol. 2001, 176, 386-390. [CrossRef]

3. Amoutzias, G.D.; Anargyros Chaliotis, A.; Mossialos, D. Discovery Strategies of Bioactive Compounds Synthesized by Nonribosomal Peptide Synthetases and Type-I Polyketide Synthases Derived from Marine Microbiomes. Mar. Drugs 2016, 14, 80. [CrossRef]

4. Antony-Babu, S.; Goodfellow, M. Biosystematics of alkaliphilic Streptomycetes isolated from seven locations across a beach and dune sand system. Antonie Leeuwenhoek 2008, 94, 581-591. [CrossRef] [PubMed]

5. Bull, A.T.; Stach, J.E.; Ward, A.C.; Goodfellow, M. Marine actinobacteria: Perspectives, challenges, future directions. Antonie Leeuwenhoek 2005, 87, 65-79. [CrossRef]

6. Pathom-aree, W.; Stach, J.E.M.; Ward, A.C.; Horikoshi, K.; Bull, A.T.; Goodfellow, M. Diversity of Actinomycetes isolated from Challenger Deep sediment (10,898 m) from the Mariana Trench. Extremophiles 2006, 10, 181-189. [CrossRef]

7. Lyutskanova, D.; Ivanova, V.; Stoilova-Disheva, M.; Kolarova, M.; Aleksieva, K.; Peltekova, V. Isolation and characterization of a psychrotolerant Streptomyces strain from permafrost soil in Spitsbergen, producing phtalic acid ester. Biotechnol. Biotechnol. Equip. 2009, 23, 1220-1224. [CrossRef]

8. Steven, B.; Pollard, W.H.; Greer, C.W.; Whyte, L.G. Microbial diversity and activity through a permafrost/ground ice core profile from the Canadian high Arctic. Environ. Microbiol. 2008, 10, 3388-3403. [CrossRef]

9. Okoro, C.K.; Asenjo, J.A.; Andrews, B.A.; Ferguson, G.; Bull, A.T.; Goodfellow, M.; Ebel, R.; Jaspars, M. Chaxamycins A-D, bioactive ansamycins from a hyper-arid desert Streptomyces sp. J. Nat. Prod. 2011, 74, 1491-1499. [CrossRef]

10. Fiedler, H.P.; Bruntner, C.; Bull, A.T.; Ward, A.C.; Goodfellow, M.; Potterat, O.; Puder, C.; Mihm, G. Marine Actinomycetes as a source of novel secondary metabolites. Antonie Leeuwenhoek 2005, 87, 37-42. [CrossRef]

11. Goodfellow, M.; Nouioui, I.; Sanderson, R.; Xie, F.; Bull, A.T. Rare taxa and dark microbial matter: Novel bioactive actinobacteria abound in Atacama Desert soils. Antonie Leeuwenhoek 2018, 111, 1315-1332. [CrossRef]

12. Santhanam, R.; Okoro, C.K.; Rong, X.; Huang, Y.; Bull, A.T.; Weon, H.Y.; Andrews, B.A.; Asenjo, J.A.; Goodfellow, M. Streptomyces atacamensis sp. nov., isolated from an extreme hyper-arid soil of the Atacama Desert, Chile. Int. J. Syst. Evol. Microbiol. 2012, 62, 2680-2684. [CrossRef]

13. Santhanam, R.; Okoro, C.K.; Rong, X.; Huang, Y.; Bull, A.T.; Andrews, B.A.; Asenjo, J.A.; Weon, H.Y.; Goodfellow, M. Streptomyces deserti sp. nov., isolated from hyper-arid Atacama Desert soil. Antonie Leeuwenhoek 2012, 101, 575-581. [CrossRef] [PubMed]

14. Santhanam, R.; Rong, X.; Huang, Y.; Andrews, B.A.; Asenjo, J.A.; Goodfellow, M. Streptomyces bullii sp. nov., isolated from a hyper-arid Atacama Desert soil. Antonie Leeuwenhoek 2013, 103, 367-373. [CrossRef]

15. Busarakam, K.; Bull, A.T.; Girard, G.; Labeda, D.P.; Van Wezel, G.P.; Goodfellow, M. Streptomyces leeuwenhoekii sp. nov., the producer of chaxalactins and chaxamycins, forms a distinct branch in Streptomyces gene trees. Antonie Leeuwenhoek 2014, 105, 849-861. [CrossRef]

16. Rateb, M.E.; Houssen, W.E.; Harrison, W.T.A.; Deng, H.; Okoro, C.K.; Asenjo, J.A.; Andrews, B.A.; Bull, A.T.; Goodfellow, M.; Ebel, R.; et al. Diverse metabolic profiles of a Streptomyces strain isolated from a hyper-arid environment. J. Nat. Prod. 2011, 74, 1965-1971. [CrossRef]

17. Nachtigall, J.; Kulik, A.; Helaly, S.; Bull, A.T.; Goodfellow, M.; Asenjo, J.A.; Maier, A.; Wiese, J.; Imhoff, J.F.; Sussmuth, R.D.; et al. Atacamycins A-C, 22-membered antitumor macrolactones produced by Streptomyces sp. C38. J. Antibiot. 2011, 64, 775-780. [CrossRef] 
18. Elsayed, S.S.; Trusch, F.; Deng, H.; Raab, A.; Prokes, I.; Busarakam, K.; Asenjo, J.A.; Andrews, B.A.; Van West, P.; Bull, A.T.; et al. Chaxapeptin, a lasso peptide from extremotolerant Streptomyces leeuwenhoekii strain C58 from the hyperarid Atacama Desert. J. Org. Chem. 2015, 80, 10252-10260. [CrossRef] [PubMed]

19. Schulz, D.; Beese, P.; Ohlendorf, B.; Erhard, A.; Zinecker, H.; Dorador, C.; Imhoff, J.F. Abenquines A-D: Aminoquinone derivatives produced by Streptomyces sp. strain DB634. J. Antibiot. 2011, 64, 763-768. [CrossRef] [PubMed]

20. Dorador, C.; Vila, I.; Witzel, K.-P.; Imhoff, J.F. Bacterial and archaeal diversity in high altitude wetlands of the Chilean Altiplano. Fundam. Appl. Limnol. 2013, 182, 135-159. [CrossRef]

21. Molina, V.; Hernandez, K.; Dorador, C.; Hengst, M.; Pérez, V. Bacterial active community cycling in response to solar radiation and their influence on nutrient changes in a high-altitude wetland. Front. Microbiol. 2016, 7, 1823. [CrossRef]

22. Dorador, C.; Vila, I.; Remonsellez, F.; Imhoff, J.F.; Witzel, K.-P. Unique clusters of Archaea in Salar de Huasco, an athalassohaline evaporitic basin of the Chilean Altiplano. FEMS Microbiol. Ecol. 2010, 73, 291-302. [CrossRef]

23. Dorador, C.; Meneses, D.; Urtuvia, V.; Demergasso, C.; Vila, I.; Witzel, K.P.; Imhoff, J.F. Diversity of Bacteroidetes in high-altitude saline evaporitic basins in northern Chile. J. Geophys. Res. 2009, 114, G00D05. [CrossRef]

24. Kuester, E.; Williams, S.T. Selection of media for isolation of Streptomycetes. Nature 1964, 202, 928-929. [CrossRef]

25. Vickers, J.C.; Williams, S.T.; Ross, G.W. A taxonomic approach to selective isolation of Streptomycetes from soil. In Biological and Biochemical Aspects of Actinomycetes; Ortiz-Ortiz, L., Bojalil, L.F., Yakoleff, V., Eds.; Academic Press: Orlando, FL, USA, 1984; pp. 553-561.

26. Shirling, E.B.; Gottlieb, D. Methods for characterization of Streptomyces species. Int. J. Syst. Bacteriol. 1966, 16, 313-340. [CrossRef]

27. Kelly, K.L. Color Name Charts Illustrated with Centroid Colors; Supplement to NBS Circular 553. Inter-Society Color Council-National Bureau of Standards (ISCC-NBS); U. S. National Bureau of Standards: Washington, DC, USA, 1964.

28. Stackebrandt, E.; Liesack, W. Nucleic Acids and Classification. In Handbook of New Bacterial Systematics; Goodfellow, M., O’Donnell, A.G., Eds.; Academic Press: London, UK, 1993; pp. 151-194.

29. Wang, Q.; Garrity, G.M.; Tiedje, J.M. Cole JR (2007) Naive bayesian classifier for rapid assignment of rRNA sequences into the new bacterial taxonomy. Appl. Environ. Microbiol. 1984, 73, 5261-5267. [CrossRef] [PubMed]

30. Kim, O.S.; Cho, Y.J.; Lee, K.; Yoon, S.H.; Kim, M.; Na, H.; Park, S.C.; Jeon, Y.S.; Lee, J.H.; Yi, H.; et al. Introducing EzTaxon-e: A prokaryotic 16S rRNA gene sequence database with phylotypes that represent uncultured species. Int. J. Syst. Evol. Microbiol. 2012, 62, 716-721. [CrossRef] [PubMed]

31. Saitou, N.; Nei, M. The neighbor-joining method: A new method for reconstructing phylogenetic trees. Mol. Biol. Evol. 1987, 4, 406-425. [CrossRef]

32. Kumar, S.; Stecher, G.; Tamura, K. MEGA7: Molecular Evolutionary Genetics Analysis Version 7.0 for Bigger Datasets. Mol. Biol. Evol. 2016, 33, 1870-1874. [CrossRef]

33. Edgar, R.C. MUSCLE: Multiple sequence alignment with high accuracy and high throughput. Nucleic Acids Res. 2004, 32, 1792-1797. [CrossRef]

34. Felsenstein, J. Evolutionary trees from DNA sequences: A maximum likelihood approach. J. Mol. Evol. 1981, 17, 368-376. [CrossRef]

35. Ayuso-Sacido, A.; Genilloud, O. New PCR primers for the screening of NRPS and PKS-I systems in Actinomycetes: Detection and distribution of these biosynthetic gene sequences in major taxonomic groups. Microb. Ecol. 2005, 49, 10-24. [CrossRef]

36. Schneemann, I.; Kajahn, I.; Ohlendorf, B.; Zinecker, H.; Erhard, A.; Nagel, K.; Wiese, J.; Imhoff, J.F. Mayamycin, a Cytotoxic Polyketide from a Streptomyces Strain Isolated from the Marine Sponge Halichondria panicea. J. Nat. Prod. 2010, 73, 1309-1312. [CrossRef] [PubMed]

37. Silber, J.; Ohlendorf, B.; Labes, A.; Erhard, A.; Imhoff, J.F. Calcarides A-E, antibacterial macrocyclic and linear polyesters from a calcarisporium strain. Mar. Drugs 2013, 11, 3309-3323. [CrossRef]

38. Buckingham, J. Dictionary of Natural Products on DVD, version 21:1; CRC Press Taylor and Francis Group: London, UK, 2012. 
39. Chun, J.; Oren, A.; Ventosa, A.; Christensen, H.; Arahal, D.R.; da Costa, M.S.; Rooney, A.P.; Yi, H.; Xu, X.W.; De Meyer, S.; et al. Proposed minimal standards for the use of genome data for the taxonomy of prokaryotes. Int. J. Syst. Evol. Microbiol. 2018, 68, 461-466. [CrossRef]

40. Lindenbein, W. Über Einige Chemisch Interessante Aktinomycetenstämme Und Ihre Klassifizierung. Arch. Mikrobiol. 1952, 17, 361-383. [CrossRef]

41. De Querioz, V.M.; Albert, C.A. Streptomyces iakyrus nov. sp., produtor dos antibióticos Iaquirina I, IIe, III. Rev. Inst. Antibiot. Univ. Recife 1962, 4, 33-46.

42. Ryabova, I.D.; Preobrazhenskaya, T.P. Problems of Classification of Actinomycetes-Antagonists; Gauze, G.F., Preobrazhenskaya, T.P., Kudrina, E.S., Blinov, N.O., Ryabova, I.D., Sveshnikova, M.A., Eds.; Government Publishing House of Medical Literature: Medgiz, Moscow, Russia, 1957; pp. 1-398.

43. Gause, G.F.; Preobrazhenskaya, T.P.; Sveshnikova, M.A.; Terekhova, L.P.; Maximova, T.S. A Guide for the Determination of Actinomycetes. Genera Streptomyces, Streptoverticillium, and Chainia; Nauka: Moscow, Russia, 1983.

44. Han, L.; Zhang, G.; Miao, G.; Zhang, X.; Feng, J. Streptomyces kanasensis sp. nov., an Antiviral Glycoprotein Producing Actinomycete Isolated from Forest Soil Around Kanas Lake of China. Curr. Microbiol. 2015, 71, 627-631. [CrossRef] [PubMed]

45. Okami, Y.; Umezawa, H. Production and isolation of a new antibiotic, kanamycin. J. Antibiot. 1957, 10, 181-189.

46. Goodfellow, M.; Williams, S.T.; Alderson, G. Transfer of Kitasatoa purpurea Matsuma and Hata to the genus Streptomyces as Streptomyces purpurea comb. nov. Syst. Appl. Microbiol. 1986, 8, 65-66. [CrossRef]

47. Onaka, H. Biosynthesis of heterocyclic antibiotics in Actinomycetes and an aproach to synthesize the natural compounds. Actinomycetologica 2006, 20, 62-71. [CrossRef]

48. Sánchez, C.; Méndez, C.; Salas, J.A. Engineering biosynthetic pathways to generate antitumor indolocarbazole derivatives. J. Ind. Microbiol. Biotechnol. 2006, 33, 560-568. [CrossRef]

49. Bowers, K.J.; Mesbah, N.M.; Wiegel, J. Biodiversity of poly-extremophilic Bacteria: Does combining the extremes of high salt, alkaline $\mathrm{pH}$ and elevated temperature approach a physico-chemical boundary for life? Saline Syst. 2009, 5, 9. [CrossRef]

50. Dorador, C.; Vila, I.; Imhoff, J.F.; Witzel, K.-P. Cyanobacterial diversity in Salar de Huasco, a high altitude saline wetland in northern Chile: An example of geographical dispersion? FEMS Microbiol. Ecol. 2008, 64, 419-432. [CrossRef] [PubMed] 